has been on different islands, but with much secondary overlap of species so that as many as fifteen occurred on a single island (Hawaii). In some species interisland stragglers are so frequent that differentiation does not oceur or is held at the racial level. The more isolated islands receive fewer stragglers, and as a result endemism is very pronounced. The larger islands have a more varied ecology than do the smaller ones. This is reflected in a richer avifauna, apparently because many species are able to survive on the larger islands by utilizing ecological niches absent on the smaller ones. Birds straggle from island to island so frequently that the relative ages of the islands of the Hawaiian group are not reflected in the composition of the bird life. In this, birds differ from more sedentary groups such as molluses.

Adaptive radiation - the occurrence of a number of very different ecological types within a taxonomic group-is usually best illustrated by families or orders; but in the Drepaniidre it occurs within the limits of a family.

\section{SCIENCE TECHNOLOGISTS ASSOCIATION}

$\mathrm{F}^{\mathrm{o}}$

OR many years technicians in science laboratories in educational institutions and industry throughout Great Britain have been conscious of the need of a professional organization to cater for that large body of laboratory technicians not covered by an association in the way, for example, medical laboratory technicians are covered by the Institute of Medical Laboratory Technology, and to provide schemes of training with the view of certification and registration at a professional level.

Early in 1948 the Science Technologists Association was formed. The training scheme as approved by the Association is a five-year course covering so far as practicable all branches of science: three years of study are required for the certificate and a further two years for the diploma, all instruction being given by experienced technicians and the emphasis being placed on the practical side of the technician's work. It may be noted that the Association is at present providing the instruction for the City and Guilds course of laboratory technician work which is now running at the Paddington Technical Institute. The honorary general secretary (Department of Chemistry, Imperial College of Science and Technology, London, S.W.7) will provide further details and syllabuses to those interested.

The president of the Association is Prof. C. H. O'Donoghue, professor of zoology in the University of Reading, and there are eight vice-presidents, all of them men of science. The president and vicepresidents, together with eighteen elected technicians, form the Council of the Association. Fourteen of the technicians also form a General Purposes Committee which acts as the executive of the Association.

There are at present four branches: London, Edinburgh, Glasgow and Cardiff. All are active and organize local activities, lectures, visits, etc., and, when possible, hold classes based on Association syllabuses. The branch at Edinburgh has been especially successful in this respect, and the classes are now running in their second year. A Bulletin is published at regular intervals.and is proving a useful means of keeping members informed of activities. A list of vacant situations is included, and the editor will be pleased to advertise any vacancies sent to him.

The Association has expanded rapidly, new members being enrolled steadily. Potential membership is very large, and the immediate aim is to build up a substantial membership to give the Association an authority in the shortest possible time. The ultimate objective, namely, the formation of an Institute with a registered address and paid officers, although still some way off, is becoming nearer. The immediate benefit of the Science Technologists Association to established technicians may not be very apparent; but it can claim to being a body which belongs to technicians and provides the opportunity for them to achieve professional status and recognition of their undoubted abilities and place in organized science.

\section{MATHEMATICAL ASSOCIATION ANNUAL MEETING AT BRISTOL}

THE annual meeting for 1951 of the Mathematical Association was held at Bristol during March 28-31, under the presidency of Prof. H. R. Hassé, professor emeritus of mathematics in the University of Bristol. Members of the Association were welcomed by the vice-chancellor of the University, Sir Philip Morris, at a reception held in Wills Hall on the evening of the first day of the meeting.

On the morning of March 29, Prof. Hassé gave his presidential address on "My Fifty Years of Mathematics", in which he traced the changes in the range and character of the teaching of mathematics to university students in the period 1900-50. Prof. Hassé considered the consequences of the abolition of the order of merit in the Mathematical Tripos at Cambridge, of the emphasis on rigorous demonstration in analysis given by Hardy and Bromwich in their books, and of the growth of a lively geometrical school under H. F. Baker; and he illustrated all this by noting the tendency to replace geometrical by analytical methods in applied mathematics, the increased use of vector methods, the destruction of the old sharp distinction between pure and applied mathematics, and the increased importance of an algebraic basis for geometry.

The Association's Teaching Committee will shortly be engaged on a revision of its report on the teaching of algebra. To direct the attention of teachers to this task, Mr. W. J. Langford (Battersea Grammar School) spoke on the teaching of algebra in schools, particularly condemning over-elaboration of manipulative technique at the expense of clear grasp of methods.

On March 30, the first item was a symposium on Modern School work, organized by Miss L. D. Adams (H.M. Inspector of Schools). Aspects of Modern School teaching were explained by three teachers from Bristol schools, and a large and varied display of work done by children in Modern Schools was exhibited. Much of this work came from Bristol schools; but items from all parts of Great Britain had been obtained and were on show. An inspection of this work gave the impression that the very considerable difficulties which confront the teacher of mathematics in the Modern' School are partially diminished by the comparative freedom under which the work is done.

Prof. C. F. Powell (University of Bristol) then gave a lecture on "Cosmic Radiation", a brilliantly 